\title{
Roles of steroid hormones in oviductal function
}

\author{
Brooke E Barton ${ }^{1, *}$, Gerardo G Herrera ${ }^{1, *}$, Prashanth Anamthathmakula ${ }^{1,2}$, Jenna K Rock ${ }^{1}$, \\ Anna M Willie ${ }^{1}$, Emily A Harris ${ }^{1,2}$, Ken-Ichi Takemaru ${ }^{3}$ and Wipawee Winuthayanon ${ }^{1,2}$ \\ ${ }^{1}$ School of Molecular Biosciences, Washington State University, Pullman, Washington, USA, ${ }^{2}$ Center for \\ Reproductive Biology, College of Veterinary Medicine, Washington State University, Pullman, Washington, USA and \\ ${ }^{3}$ Department of Pharmacological Sciences, Stony Brook University, Stony Brook, New York, USA
}

Correspondence should be addressed to W Winuthayanon; Email:w.winuthayanon@wsu.edu

*(B E Barton and G G Herrera contributed equally to this work)

\begin{abstract}
The oviduct (known as the fallopian tube in humans) is the site for fertilization and pre-implantation embryo development. Female steroid hormones, estrogen and progesterone, are known to modulate the morphology and function of cells in the oviduct. In this review, we focus on the actions of estrogen and progesterone on secretory, ciliated, and muscle cell functions and morphologies during fertilization, pre-implantation embryo development, and embryo transport in humans, laboratory rodents and farm animals. We review some aspects of oviductal anatomy and histology and discuss current assisted reproductive technologies (ARTs) that bypass the oviduct and their effects on embryo quality. Lastly, we review the causes of alterations in secretory, ciliated, and muscle cell functions that could result in embryo transport defects.

Reproduction (2020) 159 R125-R137
\end{abstract}

\section{Gross anatomy and cell physiology of the oviduct}

The oviduct is a tubular organ that connects the ovary and the uterus. In humans, the oviduct is referred to as the fallopian tube. We will use the term 'the oviduct' hereafter for continuity. In humans, the oviduct is curved, whereas in some mammals, especially in rodents, is coiled. The oviduct is the site of fertilization, pre-implantation embryo development and is made up of five main regions: the fimbria, the infundibulum, the ampulla, the isthmus, and the uterotubal junction (Fig. 1). The fimbria, a fringe of finger-like structures projecting from the infundibulum, is responsible for egg 'pick-up' into the oviduct after ovulation. The fimbria and infundibulum are adjacent to the ampulla, where fertilization occurs. The isthmus and uterotubal junction (UTJ) are the proximal regions of the oviduct. The UTJ then exits into the uterine cavity. The isthmus functions as a sperm reservoir and is also thought to limit polyspermy by allowing only a gradual entry of sperm into the ampulla (reviewed by Suarez 2002).

The primary regions of the oviduct are joined by distinct segments. First, the ampullary-isthmic junction (AIJ) separates the ampulla from the isthmus. At the AlJ, there is a transition from tall and branching mucosal folds in the ampulla, to shorter and simpler folds in the isthmus. The smooth muscle transitions from a thin layer in the ampulla to a thick layer in the isthmus. Lastly, the UTJ (also known as the intramural portion of the oviduct in humans) joins the isthmus to the uterus. In numerous species (such as rats, mice, pigs and cows), the UTJ facilitates the regulation of sperm entering the oviduct (reviewed by Holt \& Fazeli 2010).

Recent findings using transgenic mice with sperm expressing fluorescent proteins showed that the majority of the sperm accumulates around the opening of the UTJ 15 min after coitus (Muro et al. 2016). Additionally, there are at least 13 proteins expressed on sperm that are required for passage through the UTJ (reviewed by Okabe 2015). For example, proteins in a disintegrin and metalloproteinase (ADAM) family (necessary for cell migration, cell adhesion, and cell interactions) are required for sperm migration to the oviduct. Specifically, ADAM1B and ADAM2 dimerize and form fertilin. The presence of fertilin in the endoplasmic reticulum of spermatids then subsequently leads to a localization of ADAM3 on the mature sperm surface. Male mice with a global deletion of Adam3 are completely sterile due to an impairment of sperm transport through the UTJ (reviewed by Fujihara et al. 2018). However, the precise mechanism of ADAM3-mediated sperm migration is still unclear. These data suggest that normal sperm motility is an important factor, but protein-protein interactions between the sperm surface and UTJ are also essential for successful sperm entry into the oviduct. 


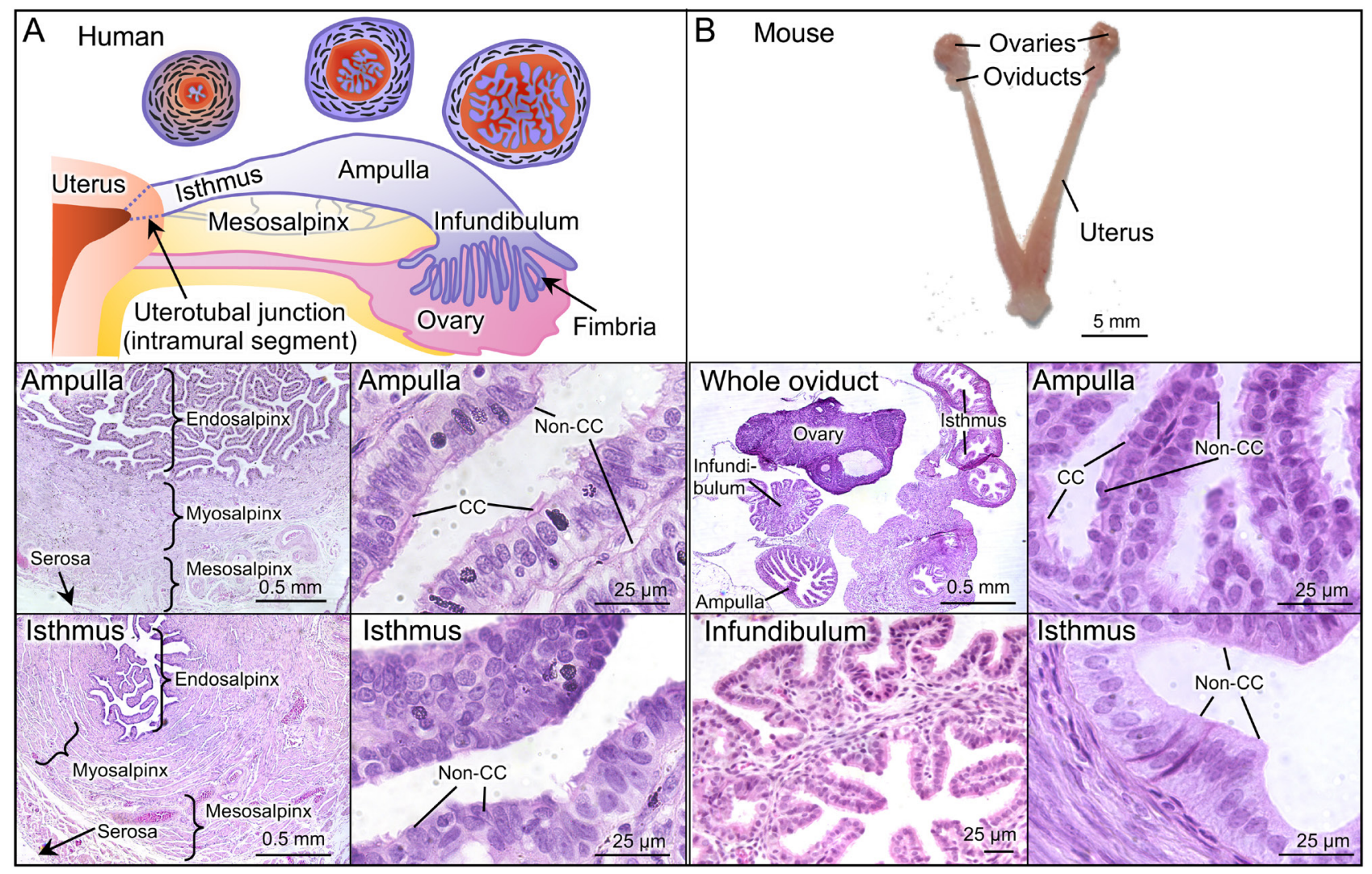

Figure 1 Gross and histological morphologies of human and mouse oviducts. (A) Human oviduct. Top panel: a drawing for gross anatomy of the oviduct. Purple and orange layers represent myosalpinx and endosalpinx layers, respectively. Middle and bottom left panels: Hematoxylin and Eosin (H\&E) staining of the ampulla and the isthmus regions of the oviduct demonstrating three tissue layers: endosalpinx, myosalpinx, and mesosalpinx. Middle and bottom right panels: Ampulla and isthmus at higher magnification. (B) Mouse oviduct. Top panel: gross anatomy of the female reproductive tract including ovaries, oviducts, and the uterus. Middle and bottom left panels: the cross section of the ovary and the whole oviduct indicating three different regions; the infundibulum, the ampulla, and the isthmus. Middle and bottom right panels: Ampulla and isthmus at higher magnification. CC, ciliated epithelial cells; non-CC, non-ciliated (secretory) epithelial cells.

The oviduct is made up of three structural components (Fig. 1A). The outside layer is the mesosalpinx, which surrounds the myosalpinx and the inner mucosal endosalpinx.

\section{Mesosalpinx}

The mesosalpinx, a part of the broad ligament, anchors the oviduct to the body wall. The outermost layer of the oviduct is the serosa (Fig. 1A). The mesosalpinx also supplies the oviduct, and the uterine and ovarian arteries, with the vascular system through the serous membrane and into the muscle layer underneath (Hunter 1988). These veins and arteries allow for circulation throughout the organ, which is partly responsible for the generation and maintenance of tubal fluid via transudation. The mesosalpinx also connects the oviduct to the lymphatic system. The interconnection of vascular, nervous, and lymphatic systems allows for the oviduct to receive all necessary nutrients as well as to eliminate waste products into lymphatic drainage.

\section{Myosalpinx}

The myosalpinx is the muscular layer of the oviduct, consisting of an outer longitudinal and an inner circular layer of smooth muscle. The use of scanning electron microscopy after tissue maceration showed that the myosalpinx contains complex networks of smooth muscle cells (SMCs) (reviewed by Muglia \& Motta 2001). Muglia and Motta demonstrated that the histoarchitecture of the myosalpinx in the oviduct varies between regions and among species. For the UTJ, the muscular layer can be classified as either a barrier-like or a sphincter-like structure depending on the species (Fig. 2A and B). Barrierlike structures are characterized by robust musculature, rich in densely packed SMC fibers (in rats and pigs). Sphincter-like structures are classified by geometrically organized independent muscle fibers, called sphincterlike type a (in rabbits and sheep). Sphincter-like type b structures show loosely interwoven plexiforms, which are characterized by uneven distributions and alignments of muscle fibers (in cows and humans). In the isthmus, bundles of SMC also orient in an intermingled fashion 

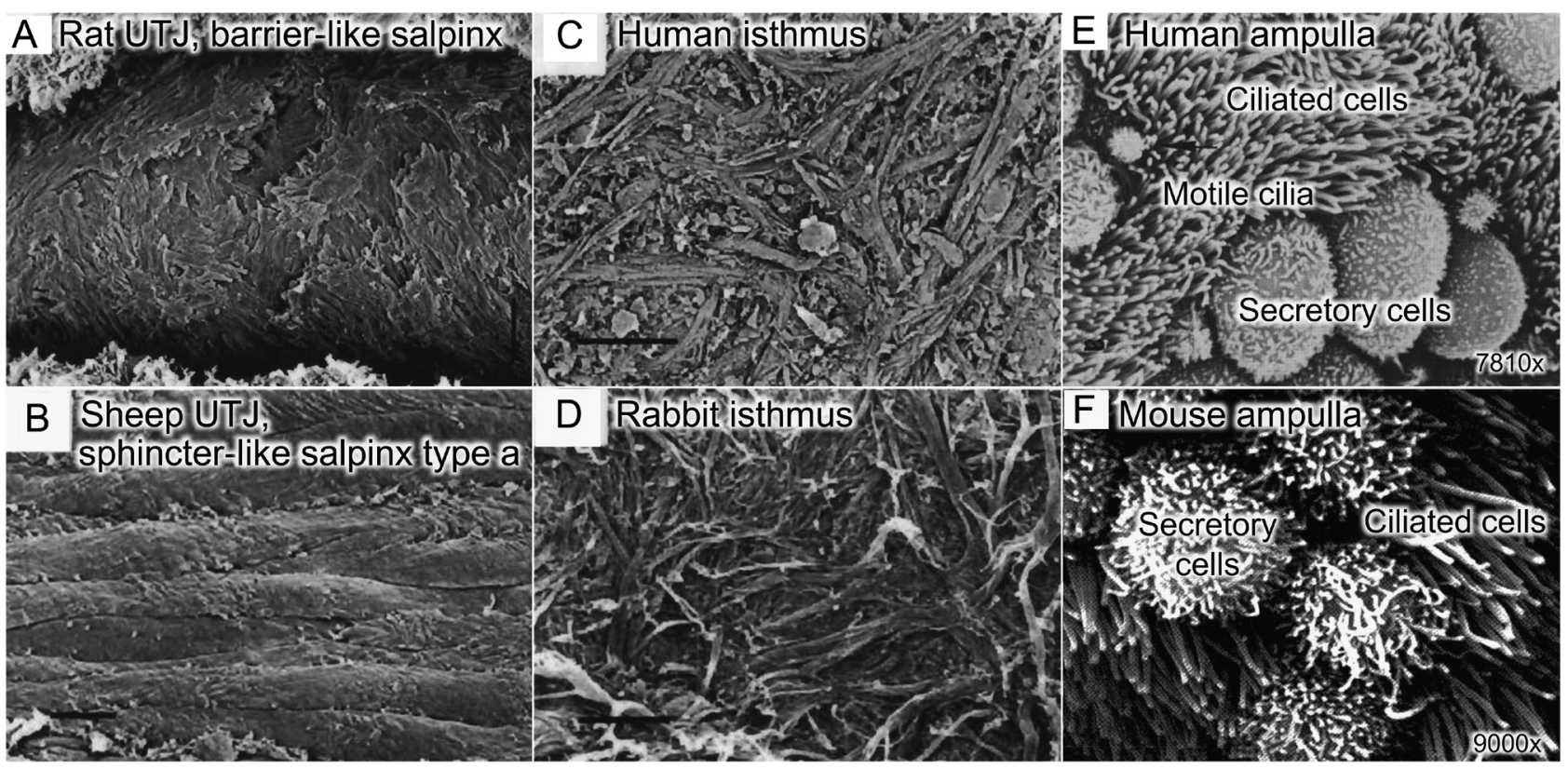

Figure 2 Scanning electron microscopy (SEM) images of the myosalpinx and the inner endosalpinx. (A, B, C and D) SEM images of the myosalpinx in the uterotubal junction (UTJ) and isthmic regions after tissue maceration techniques (adapted from (Muglia \& Motta 2001) with permission with original scale bars shown). (A) Barrier-like salpinx in rat UTJ, bar $=25 \mu \mathrm{m}$. (B) Sphincter-like type a salpinx in ewe UTJ, bar $=5$ $\mu \mathrm{m}$. (C) Plexiform arrangement of myosalpinx in the isthmus in (C) human (bar $=100 \mu \mathrm{m})$ and (D) rabbit (bar $=50 \mu \mathrm{M})$. (E and F) SEM images of inner endosalpinx at the ampulla region including ciliated and non-ciliated (or secretory) epithelial cells from (E) human oviduct $(x 7810$ magnification, modified with permission from (Seki et al. 1978)) and (F) mouse oviduct ( $\times 9000$ magnification, modified with permission from (Dirksen \& Satir 1972)). Motile cilia are present at the apical membrane of ciliated cells and microvilli are present on the apical surface of secretory cells.

which gives rise to a plexiform musculature (Fig. 2C and D). In humans, the myosalpinx in the ampulla is comprised of bundles of inner and outer SMC arranged into clockwise and counter-clockwise spiral fibers that also intermingle into a plexiform.

Muscle contractions in the oviduct facilitate sperm transport to the fertilization site and oocyte transport to the uterus. In mice, a specialized network of pacemaker cells called interstitial cells of Cajal generate slow electric waves that underlie myosalpinx contractions (Dixon et al. 2010). In humans, similar cells have been identified and are referred to as interstitial cells of Cajal-like cells (Popescu et al. 2005). The myosalpinx contracts and relaxes depending on different levels of steroid hormones, which will be discussed in a later section. Muscle contractions create a back-and-forth motion of the oocytes/embryos within the oviduct before arrival to the uterus. In rodents, peristaltic contractions of the myosalpinx result in movement of tubal fluid that is crucial for sperm transport from the isthmus to the ampulla (Hino \& Yanagimachi 2019). As shown in Fig. $1 \mathrm{~A}$, the myosalpinx is thicker in the isthmus than in the ampulla or infundibulum.

\section{Endosalpinx}

The endosalpinx is the inner mucosal layer of the oviduct and is comprised of epithelial cells and lamina propria mucosa (Castro et al. 2019). The lamina propria mucosa is a network of connective tissues containing fibroblasts (or stromal cells) and other mononuclear cell populations (Pauerstein \& Eddy 1979). In mammals, the oviductal epithelium is made-up of secretory (or non-ciliated) and ciliated epithelial cells (Fig. 2E and F). Secretory epithelial cells are characterized by the presence of microvilli on the apical surface. In contrast, ciliated epithelial cells have motile cilia at the apical surface.

\section{Functions of epithelial and muscle cells of the oviduct}

The fine-tuning of tubal fluid flow aids in the fertilization of eggs and congruent transport of embryos from the oviduct into the uterus. Approximate duration of embryo transport varies between species. In pigs, embryos do not enter the uterus until 2 days post fertilization. In other species, this embryo transport takes longer, with embryos exiting the oviduct closer to 3 days in mice and cows, and $\sim 3.5$ days in humans (reviewed by Croxatto 2002). Recently developed optical coherence microscopy for in vivo imaging in mice showed that zygotes are located in the ampulla at 0.5 days post-coitus (dpc) (Moore et al. 2018). Furthermore, at $1.5 \mathrm{dpc}$, two-cell embryos are in the isthmus and at day 3 , embryos are generally located in the UTJ. 


\section{Secretory cells}

Secretory cells are abundant in the proximal region of the oviduct, specifically throughout the isthmus (Fig. 3). Recent findings using lineage tracing showed that some secretory cells in mouse neonatal oviducts act as epithelial progenitors, giving rise and differentiating into both secretory and ciliated epithelial cells (Ghosh et al. 2017). Using in vivo ligation in mice, it was found that secretory cells in the isthmus continuously secrete fluid into the oviductal lumen (Hino \& Yanagimachi 2019), in addition to the transudation mechanism previously described. Tubal fluid is comprised of ions, energy substrates (such as glucose, pyruvate and lactate), amino acids, prostaglandins (PGs), steroid hormones $\left(\mathrm{E}_{2}\right.$ and $\left.\mathrm{P}_{4}\right)$ as well as various proteins (such as albumin, glycoproteins and lipoproteins) and growth factors (including EGF, fibroblast growth factor (FGF), transforming growth factor (TGF), insulin-like growth factor (IGF), and IGFbinding protein (IGFBP)) (reviewed by Aguilar \& Reyley 2005). There are several secreted proteins in tubal fluid that contribute to embryo development and transport (reviewed by Coy \& Yanagimachi 2015).

One factor from secretory cells is oviductal glycoprotein 1 (OVGP1, encoded by Muc9 gene). OVGP1 is involved in sperm capacitation, sperm-oocyte binding, oocyte penetration, modification of the zona pellucida (ZP), and regulation of polyspermy (Avilés et al. 2010). In pigs and cows, incubation of oviductal fluid-containing OVGP1 significantly reduces spermZP binding and subsequently prevents polyspermy (Coy et al. 2008), potentially through increased resistance of proteolytic digestion of ZP and decreased affinity for sperm binding due to modified ZP proteins. Recent studies showed that the presence of recombinant porcine OVGP1 improves fertilization rates (Algarra et al. 2016) but does not affect developmental rates of bovine embryos (Algarra et al. 2018). In mice, OVGP1 is localized to perivitelline space but does not bind to the ZP (Kapur \& Johnson 1986). However, in a subsequent study, OVGP1 was shown to be associated with the ZP of the ovulated oocyte and facilitates sperm-ZP adhesion (Lyng \& Shur 2009). Nevertheless, global deletion of Ovgp1 in mice has no fertility defect (Araki et al. 2003). Moreover, Ovgp1 is a pseudogene in rats and horses (Avilés et al. 2010). These findings suggest that the functional significance of OVGP1 in female fertility varies among species.

Another important protein is fetuin B, a liver-derived plasma protein that is also expressed locally in the oviduct in response to estrogen signaling (Winuthayanon et al. 2015). In mice, fetuin B is essential for fertilization, as global deletion of Fetub causes female infertility (Dietzel et al. 2013). Therefore, it is likely that secretory cells of the oviduct facilitate fertilization and pre-implantation embryo development by secreting necessary factors into the oviductal lumen.

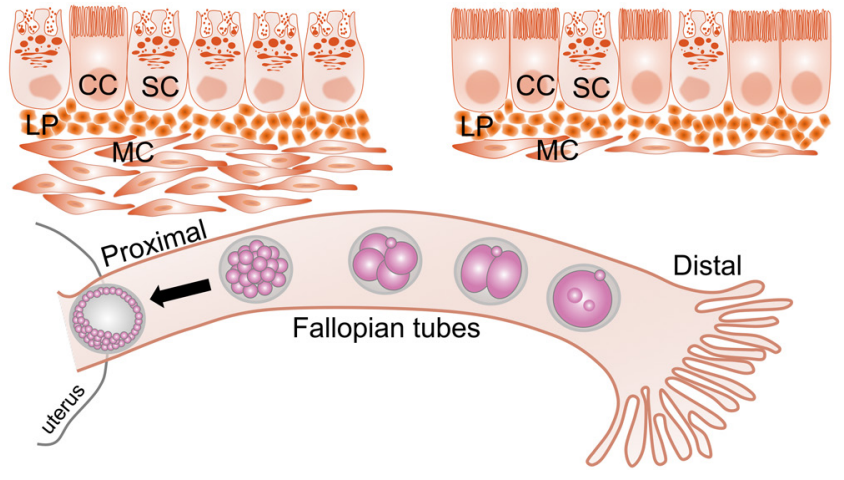

Figure 3 Ciliated epithelial cells (CC) are more abundant in the distal part of the oviduct (including infundibulum and ampulla), whereas the secretory epithelial cells (SC) are more prominent in the proximal part including the isthmus. Muscle cell (MC) layer is also thickest in the proximal compared to the distal region of the oviduct (as also seen in the histological analysis in Fig. 1). Lamina propria (LP) represents fibroblasts underneath epithelial cells in the mucosal folds. Zygote, two-cell, four- to eight-cell, morula, and blastocyst stage embryo develops within the oviducts before the transport into the uterine cavity.

\section{Ciliated cells}

Ciliated cells are most abundant in the infundibulum and ampulla (Figs 1 and 3). There are two proposed functions of oviductal cilia in reproduction: (1) to facilitate movement of tubal fluid and embryos toward the uterus and (2) to create a rheotaxis signal for sperm to reach the ampulla (Miki \& Clapham 2013). However, recent in vivo studies by Hino and Yanagimachi showed that rheotaxis does not seem to play a role in sperm movement in mice (Hino \& Yanagimachi 2019). Therefore, the function of unidirectional flow generated by ciliated epithelial cells is still under controversy. Nevertheless, a genetic study in mice showed that cilia of appropriate length are essential for oviductal function as a global loss of Kif19 gene (kinesin family member 19) has significantly longer cilia in the oviduct compared to controls (Niwa et al. 2012). These elongated cilia in Kif $19^{-/-}$females led to an ineffective fluid flow causing an obstruction of cell debris and an occluded lumen, resulting in complete sterility. In contrast, conditional deletion of Cep164, encoding a key ciliary protein and central regulator of primary ciliogenesis, in ciliated cells caused a reduction in both length and number of multicilia compared to control mice (Siller et al. 2017). Surprisingly, these female mice lacking Cep164 in ciliated cells are fertile, indicating that if the oviductal lumen is not occluded, eggs and embryos are able to transport to the uterus and that shortening cilia has no overt effect on fertility in mice.

In mice, ciliary beat frequency (CBF) cycles at 7-10 Hertz $(\mathrm{Hz})$ at $0.5 \mathrm{dpc}$ and decreases significantly to 2.5-5.0 Hz at $2.5 \mathrm{dpc}$ (Wang et al. 2015, Li et al. 2017). It is likely that this reduction in CBF at $2.5 \mathrm{dpc}$ decelerates the luminal fluid flow and helps retain the 
embryo within the oviduct to prevent the premature arrival of the embryos into the uterus before $3.5 \mathrm{dpc}$.

\section{Muscle cells}

The layer of smooth muscle cells is thicker in the isthmus than in the ampulla (Figs 1 and 3). Contraction of smooth muscle cells results in an increased velocity of fluid flow. As mentioned earlier, muscle contraction is a major contributor to adovarian tubal fluid flow, supporting sperm transport from the isthmus to the ampulla (Hino \& Yanagimachi 2019). It is also postulated that muscle contraction facilitates the embryo transport process, in addition to the function of cilia. Studies in rats and rabbits showed that in the absence of smooth muscle contraction after treatment with isoproterenol, a $\beta$-adrenergic agonist, ciliated cells were able to make up most of the tubal flow and egg transport was not affected (Halbert et al. 1976, 1989). However, a study in mice showed that disruption of cannabinoid receptor $\left(\mathrm{Cnr}^{--}{ }^{-}\right)$resulted in impaired embryo transport due to an alteration of smooth muscle contraction and relaxation (Wang et al. 2004). In mouse oviducts, one of the $\mathrm{Ca}^{2+}$ activated $\mathrm{Cl}^{-}$channels protein called anoctamin-1, encoded by Tmem16a gene, in the interstitial cells of Cajal in the myosalpinx, is responsible for the generation of spontaneous slow electrical wave and may be involved in egg transport (Dixon et al. 2012). Dixon et al. showed that the oviduct from Tmem $16 \mathrm{a}^{-/-}$females completely lack their slow wave activity. However, whether this slow wave generated by interstitial cells of Cajal is required for female fertility remains unclear as Tmem $16 \mathrm{a}^{-1-}$ mice die before puberty. Overall, oviductal muscle contraction does plays a crucial role in female reproduction but appears to vary among species and therefore must be the subject of future investigations as the mechanisms are widely unknown.

\section{Roles of estrogen and progesterone in oviductal function}

Estrogen $\left(E_{2}\right)$ and progesterone $\left(P_{4}\right)$ are female steroid hormones that act through nuclear and membrane receptors. $E_{2}$ is produced by granulosa cells in the ovary and exhibits its activity through estrogen receptor $\alpha$ and $\beta$ (encoded by Esr 1 and Esr2 genes) (Hewitt et al. 2016). $\mathrm{P}_{4}$ is secreted from peri-ovulatory granulosa and luteal cells and acts through progesterone receptors (encoded by Pgr gene) (Conneely et al. 2003, Mulac-Jericevic et al. 2003). In mice and rats, ESR1 is expressed in epithelial, stromal, and muscle cells of the oviduct (Okada et al. 2003, Winuthayanon et al. 2015) (Fig. 4). Comparatively, immunohistochemical analysis of PGR showed higher expression in stromal and muscle cells compared to epithelial cells in the infundibulum and ampulla, respectively, while PGR expression is observed in all three

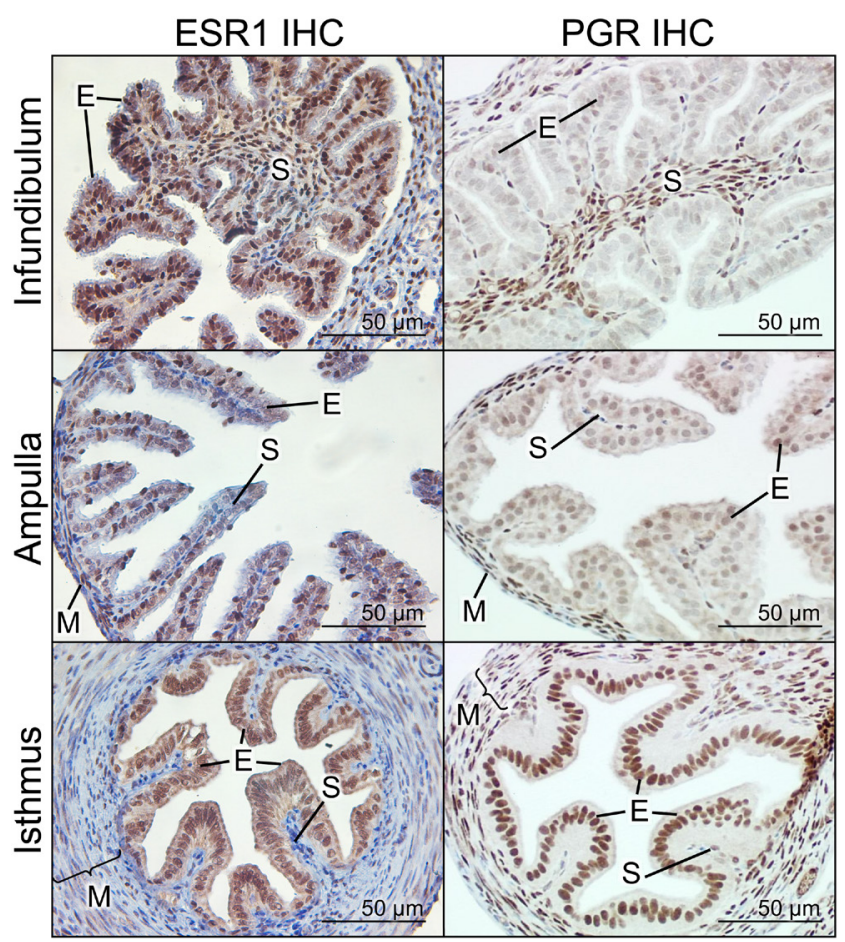

Figure 4 Expression of estrogen and progesterone receptor (ESR1 and $P G R)$ proteins in the mouse oviduct at the infundibulum, the ampulla, and the isthmus. Oviducts were randomly collected from female mice at different stages of the estrus cycle. E, epithelium; M, muscle cells; $\mathrm{S}$, stroma.

cell types in the isthmus of mouse oviducts (Fig. 4). In addition to classical nuclear receptors, $\mathrm{P}_{4}$ also functions through membrane progesterone receptors (mPRs) and their expression is tissue specific (Kowalik et al. 2013). Nutu et al. showed that $\mathrm{mPR} \beta$ protein is detected in the cilia, whereas the mPR $\gamma$ is localized at the apical plasma membrane of ciliated cells in mouse oviducts and human oviducts (Nutu et al. 2009).

Classical studies from the 1950s-1990s in several species have described that both secretory and ciliated cells change their morphology in response to changes in levels of $E_{2}$ and $P_{4}$ (reviewed by Abe 1996). As shown in rhesus monkeys (Brenner 1969), epithelial cells of the oviduct in the fimbria are cuboidal at day 2 of the menstrual cycle (Fig. 5). At days 5-6 (follicular phase, high levels of circulating $E_{2}$ ), epithelial cell height drastically increases and ciliation is observed. At day 15 (early luteal phase, $\mathrm{E}_{2}$ level declines while $\mathrm{P}_{4}$ level rises), the epithelial cells regress and atrophy (decreased cell height and underwent partial de-ciliation as ciliary apparatus pinched off and shed into the lumen). At the end of the menstrual cycle, in which both $E_{2}$ and $P_{4}$ are at basal levels (day 27), the epithelial cells return to cuboidal morphology and cilia are rarely present. Unlike the fimbria and ampulla, ciliated and secretory cells in the isthmus do not drastically regress during luteal phase (Steffl et al. 2008). Whether or not these 


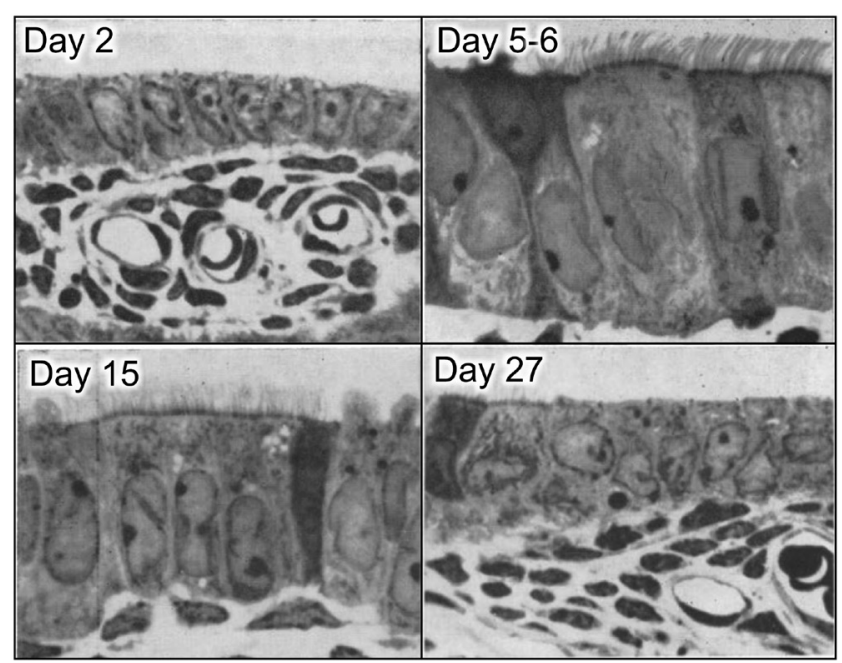

Figure 5 Images from light microscopy of epithelial cell layer of oviducts collected from the fimbria region at different days of the menstrual cycle in Rhesus monkeys. Days 2, 5-6, 15, and 27 represent days after menstruation. All images are taken at $\times 1200$ magnification (adapted from Brenner 1969 with permission).

ciliated cells undergo apoptotic cell death and renew each cycle is still debatable and appears to vary among species (Steffl et al. 2008). As mentioned earlier, secretory cells in neonatal mouse oviducts could give rise to the ciliated cell population, driven by $\mathrm{Wnt} / \beta$ catenin signaling pathway, due to its pluripotency during development (Ghosh et al. 2017). However, it is unlikely that these terminally differentiated de-ciliated epithelial cells could become secretory cells during luteal phase.

In the oviduct, both $\mathrm{E}_{2}$ and $\mathrm{P}_{4}$ have also been shown to modulate sperm function in the female reproductive tract. In humans, $\mathrm{P}_{4}$, secreted from cumulus cells, was shown to be a chemoattractant for sperm (OrenBenaroya et al. 2008). The presence of $P_{4}$ increased intracellular $\mathrm{Ca}^{2+}$ in sperm flagella through the potentiation of CatSper, a pH-dependent $\mathrm{Ca}^{2+}$ channel in human sperm (Lishko et al. 2011). The effect of $P_{4}$ on sperm motility appears to be mediated by $\mathrm{mPR} \alpha$ (Tan et al. 2019), not classical PGRs (Lishko et al. 2011). These data are supported by the finding that global deletion of $\mathrm{Pgr}\left(\mathrm{Pgr}^{-/-}\right)$has no effect on male fertility in mice (Lydon et al. 1995). Inhibition of mPR activity also significantly decreases acrosome reactions in human sperm (Sabeur et al. 1996). These findings indicate that $\mathrm{P}_{4}$ acts as a chemotactic cue and stimulates capacitationrelated events in human sperm. In contrast, the mechanism and effects of $E_{2}$ on sperm capacitation and motility are less defined. ESR1 and ESR2 are expressed in the head and midpiece of human sperm, respectively (Solakidi et al. 2005). In mice, treatment of sperm with $\mathrm{E}_{2}$ significantly increases capacitation and acrosome reactions (Adeoya-Osiguwa et al. 2003). Additionally, studies using a global Esr1-knockout mouse model $\left(E s \mathrm{r}^{--}\right)$showed a severe reduction in sperm motility and sperm count, leading to an inability to fertilize eggs in vitro (Eddy et al. 1996). However, the defect in $\mathrm{Esr}^{-/-}$mice appears to be due to a disruption of spermatogenesis and seminiferous tubule development.

\section{Steroid action in secretory epithelial cells}

Tubal fluid is produced not only by transudation of fluid from capillaries, as mentioned above, but also by the secretory cells that line the oviduct. Oviducts are filled with this tubal fluid that not only nourishes and protects the egg and embryo but also maintains sperm motility, viability and storage and aids in embryo transport to the implantation site. In rats and pigs, expression of aquaporins (water channels encoded by Aqp genes; including Aqp5, Aqp8, and Aqp9, on the apical plasma membrane along the oviduct) is regulated by both $\mathrm{E}_{2}$ and $\mathrm{P}_{4}$ (Brañes etal. 2005, Skowronski et al. 2011). In mice the expression of Aqp5, specific to secretory cells, is highest during estrus when $E_{2}$ levels peak (Nah et al. 2017). As such, these aquaporins may contribute to the regulation of fluid within the oviductal lumen. Accordingly, Hino and Yanagimachi showed that, at estrus, the isthmus region produced approximately $2.2 \mu \mathrm{L}$ of fluid per hour in mice (Hino \& Yanagimachi 2019). In cows, sheep and rabbits, oviductal fluid volume drastically increases after $\mathrm{E}_{2}$ treatment or at estrus (McDonald \& Bellve 1969, Roberts et al. 1975, Gott et al. 1988). Therefore, $E_{2}$ is a positive regulator for secretory function in the oviduct.

In addition to fluid production, $E_{2}$ also increases oviductal protein production. Some of these secreted proteins, called embryotrophic factors, are postulated to be involved in embryo development (Avilés et al. 2010). These factors include OVGP1 (Buhi et al. 1992, Chen et al. 2013), demilune cell and parotid protein (DCPP) (Lee et al. 2006), insulin-like growth factorbinding proteins (IGFBP) (Lai et al. 1996), among others (Bauersachs et al. 2003). In addition to positive regulation of embryo development, our group also found that $E_{2}$ through ESR1 in oviductal epithelial cells is necessary for in vivo embryo protection, as deletion of Esr 1 in these cells leads to embryo death prior to the two-cell stage (Winuthayanon et al. 2015). This defect is mainly due to excess protease activity in the oviductal lumen, resulting in a disruption of embryonic plasma membranes.

$P_{4}$ has the opposite effect of $E_{2}$. When $P_{4}$ levels are high, such as during the luteal phase, aquaporin expression and fluid secretions decrease (McDonald \& Bellve 1969, Skowronski et al. 2011). In rabbits, oviductal fluid production is attenuated when $\mathrm{P}_{4}$ is administered alone or co-administered with $\mathrm{E}_{2}$ (Bishop 1956), suggesting that $P_{4}$ opposes $E_{2}$-induced fluid secretion. It was also found that rabbits treated with $\mathrm{P}_{4}$ have higher protein content in the oviductal fluid when compared to non-treated controls, suggesting that $\mathrm{P}_{4}$ increases protein concentration and alters the viscosity of the oviductal fluid (Hamner \& Fox 1968). In primary 
porcine oviductal epithelial cells, treatment with $\mathrm{P}_{4}$ is correlated with a decrease in OVGP1 expression (Chen et al. 2013). A combination of decreasing fluid production and increasing protein content characterizes the negative regulatory effects of $\mathrm{P}_{4}$ on oviductal fluid. Therefore, $\mathrm{E}_{2}$ and $\mathrm{P}_{4}$ oppositely affect the production of tubal fluid and work in a balanced unison throughout the estrous/menstrual cycle to maintain appropriate fluid levels and protein content.

\section{Steroid actions in ciliated epithelial cells}

The function of ciliated epithelial cells is crucial for recruiting the released egg to the ampulla. Ciliated cells, in addition to muscle cells, create tubal fluid flow in the oviduct. As shown in Fig. 5, the length of cilia in rhesus monkey is increased in the presence of $E_{2}$ and decreased by $\mathrm{P}_{4}$ (Brenner 1969). Normal cilia formation in female mice with a global loss of Esr1 $\left(\mathrm{Esr}^{-/-}\right)$suggests that ESR1 is not required for ciliogenesis in the oviduct (Okada et al. 2004). However, $E_{2}$ induces the differentiation of ciliated epithelial cells in rats by neonatal day 5, leading to the conclusion that $E_{2}$ facilitates but is not required for cilia development (Okada et al. 2004). Additionally, Okada et al. showed that inhibition of ESR activity using ESR antagonist, ICI182,780, hinders ciliary differentiation in neonatal rat oviducts. Our recent studies showed that loss of ESR1 in oviductal epithelial cells ( $E s r 7^{\mathrm{d} / \mathrm{d}}$ ) causes an increase in ciliary length and decrease in CBF compared to control littermates, resulting in complete embryo retention in the oviduct and failed implantation ( $\mathrm{Li}$ et al. 2017). Although ESR2 is exclusively expressed in the cilia of oviductal ciliated epithelial cells, thea global deletion of Esr2 ( $\mathrm{Esr}^{-{ }^{--}}$) does not affect embryo transport (Li et al. 2017). These findings indicate that $E_{2}$ signaling through ESR1 is crucial for the regulation of length and function of cilia in mouse oviduct and that signaling through ESR2 may be secondary.

$\mathrm{P}_{4}$ has the opposite effect of $E_{2}$ in regard to ciliation. High circulating level of $\mathrm{P}_{4}$ causes de-ciliation and decreases CBF (Brenner 1969, Mahmood et al. 1998). In mice, cows and humans, treatment with $\mathrm{P}_{4}$ causes a rapid decrease in CBF in the oviduct (Mahmood et al. 1998, Wessel et al. 2004, Bylander et al. 2010). However, global deletion of Pgr in mice has no effect on ciliogenesis as cilia remain present in the oviductal epithelial cells of $\mathrm{Pgr}^{-1-}$ females (Akison et al. 2014). Treatment with RU486, a PGR antagonist, suppresses $\mathrm{P}_{4}$-mediated actions on CBF (Bylander et al. 2013) suggesting a requirement of classical PGR regulation for ciliated cell activity in the oviduct.

Transient receptor potential cation channel subfamily $\checkmark$ member 4 (or TRPV4) was shown to regulate $\mathrm{Ca}^{2+}$ intracellular influx and the beating of ciliated epithelial cells (Lorenzo et al. 2008). In hamsters, activation of TRPV4 caused an increase in oviductal CBF (Andrade et al. 2005). Expression of TRPV4 protein in both human airways and mammary gland epithelial cells, as well as in vascular smooth muscle cells, is suppressed by $\mathrm{P}_{4}$ treatment (Jung et al. 2009). As such, the action of $\mathrm{P}_{4}$ on decreasing CBF may also result from a suppression of TRPV4 expression in ciliated epithelial cells in addition to classical steroid hormone regulation of oviductal CBF.

\section{Steroid action in muscle cells}

Both ESR1 and PGR proteins are detected in the muscle cell layers of the oviduct in rodents (Okada et al. 2003, Winuthayanon et al. 2015) as shown in Fig. 4. In rats, $E_{2}$ increases contraction of primary smooth muscle cells through a non-genomic mechanism via the induction of inositol trisphosphate production (Reuquén et al. 2015). In cows, rabbits and rats, $\mathrm{E}_{2}$ and $\mathrm{P}_{4}$ are involved in the production of PGs (especially $\mathrm{PGE}_{2}$ and $\mathrm{PGF}_{2 \alpha}$ ) and endothelins (EDNs) in oviductal epithelial cells, which are crucial for oviductal muscle contractility (Spilman 1974, Rosselli et al. 1994a,b, Wijayagunawardane et al. 1999, Al-Alem et al. 2007, Parada-Bustamante et al. 2012).

In rats, $E_{2}$ upregulates the expression of cyclooxygenase-2 (COX2; enzyme responsible for biosynthesis of PG precursor) in oviductal epithelial cells, leading to an increase in the production of PGs in the whole oviductal tissue (Pérez Martínez et al. 2006). Therefore, it is possible that oviductal epithelial cells are a source of PGs production in rats that subsequently acts on muscle cells. However, direct evidence to support this speculation has not been evaluated. In cows, treatment with $E_{2}$ increased the expression of PG synthetases and prostanoid receptors (EP2, EP4, and FP) within the smooth muscle cells of the oviduct (Huang et al. 2015, 2018). When bound to PGs, EP2 and FP increase contraction and EP4 decreases contraction (Huang et al. 2015), therefore resulting in an increased rate of oviductal contraction. Overall, $E_{2}$ acts through $P G s$ and EDNs to increase tubal contractility.

$\mathrm{P}_{4}$, on the other hand, decreases muscle contractility in the oviduct to induce relaxation. In cows, EDN1 mRNA in epithelial cells and the production of $\mathrm{PGE}_{2}$ and $\mathrm{PGF}_{2 \alpha}$ are lowest during the luteal phase, at which circulating $\mathrm{P}_{4}$ is elevated (Wijayagunawardane et al. 2001, Priyadarsana et al. 2004). Corresponding to levels of EDN1, $\mathrm{PGE}_{2}$ and $\mathrm{PGF}_{2 \alpha^{\prime}}$ tubal contraction is also significantly lower during the luteal phase compared to the follicular or post-ovulatory phases (Wijayagunawardane et al. 2001).

In summary, a fine-tuned balance of $\mathrm{E}_{2}$ and $\mathrm{P}_{4}$ action plays a crucial role in secretory and ciliated epithelial cells as well as muscle cells in the oviduct during sperm transport, fertilization, embryo transport, and embryo development. Collectively, $\mathrm{E}_{2}$ and $\mathrm{P}_{4}$ have direct and opposing effects on ciliated, secretory, and muscle cell types to prepare the microenvironment in the oviduct for successful establishment of early pregnancy (summarized in Fig. 6). 


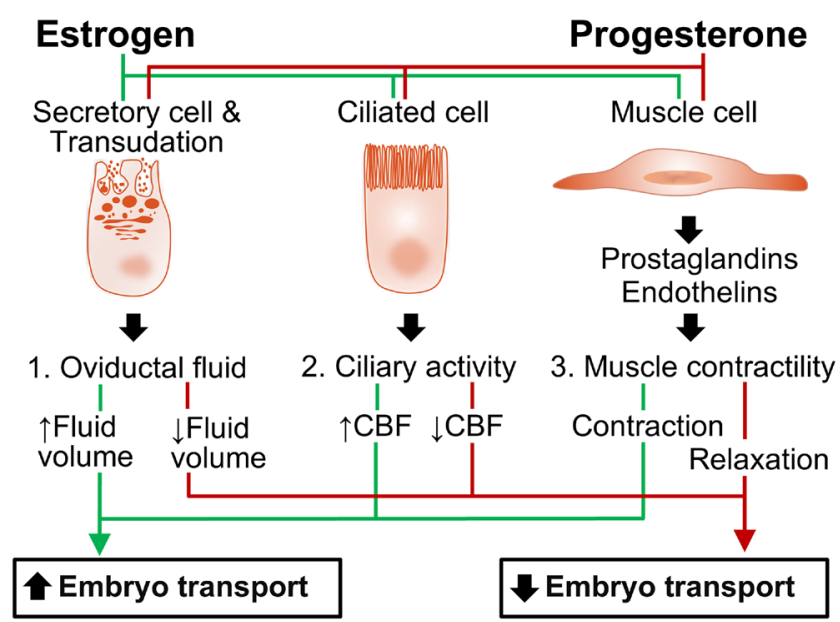

Figure 6 Actions of estrogen and progesterone in the oviductal cells in the oviducts. Estrogen and progesterone exhibit different effects on secretory, ciliated, and muscle cells in the oviduct. Estrogen- and progesterone-mediated signals are represented with green and red lines, respectively. The overall summation of estrogen and progesterone action is to increase and decrease the embryo transport rate, respectively, within the oviduct. CBF, ciliary beat frequency.

\section{Defective oviductal function}

\section{Potential negative effects of assisted reproductive technologies (ARTs) when the oviduct is bypassed}

Assisted reproductive technologies (ARTs) are fertility treatments that include artificial insemination, ovarian stimulation, gamete intra-fallopian transfer (GIFT), zygote intra-fallopian transfer (ZIFT), intrauterine insemination, in vitro fertilization (IVF) and embryo transfer (ET). GIFT and ZIFT procedures allow gametes to fertilize or embryos to develop inside the oviduct. IVF procedures, however, require fertilization to occur in a culture dish. Fertilized eggs are developed in culture to cleavage or blastocyst stages, when the embryos are then transferred into the uterine cavity. IVF includes a specialized procedure in which sperm are injected directly into the oocyte's cytoplasm, called intracytoplasmic sperm injection (ICSI). Eggs fertilized by ICSI are also developed to blastocyst stage. As such, we will refer to 'IVF' for both IVF and ICSI techniques. As a result, IVF bypasses the entire oviduct, whereas GIFT and ZIFT utilize the oviduct for fertilization and/ or pre-implantation embryos to develop in vivo. In the United States, more than 99\% of all ARTs performed are IVF procedures (Sunderam et al. 2017) compared to 65\% in Europe (De Geyter et al. 2018).

The Developmental Origins of Health and Disease $(\mathrm{DoHaD})$ hypothesis argues that the environment with which a fetus interacts in utero can have lasting effects on the health of the offspring (reviewed by Wadhwa et al. 2009); yet, it is less conclusive concerning the effect of the oviductal environment on the embryo prior to uterine implantation. Because human embryos undergo genome activation (i.e., activation of transcription) during day 3 of development (at 4-8-cell stage) while traveling through the oviduct (Braude et al. 1988), it is crucial that the embryo is subjected to the optimal microenvironment within the oviduct to support proper embryonic genome activation. As GIFT and ZIFT are less common in comparison to IVF (Sunderam et al. 2017), it is difficult to accurately compare the incidence of diseases in babies-conceived and developed in the presence (GIFT and ZIFT) or the absence (IVF and ICSI) of oviducts. Nevertheless, ARTs have been shown to alter the epigenome of resulting offspring in mice and humans as well as to increase the frequency of epigenetic disorders such as Angelman or Beckwith-Wiedemann syndromes (reviewed by Uyar \& Seli 2014).

Early studies showed that co-culturing gametes or fertilized eggs with epithelial cells improved both fertilization rates and embryo quality (Bongso et al. 1989, White et al. 1989). In mice and cows, introduction of oviductal fluid extracellular vesicles (oEVs) have been shown to improve embryo development, cryoresistance (Almiñana et al. 2017, Lopera-Vasquez et al. 2017) and increase ARTs birth rates in mice (Qu et al. 2019). In cows, oEVs secreted from oviductal epithelial cells in vivo (obtained by flushing oviducts) compared to oEVs obtained from in vitro primary oviductal epithelial cell culture presented different proteins, among which notably, OVGP1 was present only in oEVs from in vivo origin (Almiñana et al. 2017). Furthermore, oEVs produced in vivo were found to be under the hormonal regulatory effects of the estrous cycle (Alminana et al. 2018). Lopera-Vasquez et al. also demonstrated that addition of oEVs collected from the isthmus improved the developmental competence and quality of bovine embryos (Lopera-Vasquez et al. 2017).

In addition to oEVs, optimal culture media for the development of embryos to the blastocyst stage in IVF settings have been developed. There are two approaches, including one-step (monophasic) media and sequential media tailored for metabolically changing embryos during different stages. However, a recent metaanalysis showed that the superiority of sequential over monophasic media for several pregnancy outcomes was still inconclusive (Sfontouris et al. 2016), suggesting a need for further studies. Efforts have also been made to improve embryo quality in ARTs by providing a simulated oviductal environment for fertilization and early embryo development ex vivo. Ferraz et al. developed a threedimensional microfluidic model of bovine oviduct epithelial cells, called an oviduct-on-a-chip, which has been shown to produce bovine embryos with epigenetic patterning more similar to that of in vivo-derived embryos compared to embryos derived using current optimized IVF protocols (Ferraz et al. 2017). Recently, pig blastocysts produced in vitro in the presence of natural reproductive fluids (follicular, oviductal and uterine fluids) showed higher quality in terms of cell 
number and hatching ability, with gene expression and methylation patterns closer to naturally conceived embryos than blastocysts produced in non-supplemented ARTs liquids (Canovas et al. 2017). Similarly, bovine blastocysts cultured in the presence of oviductal and uterine fluids supported embryo development and improved blastocyst cryosurvival, DNA methylation and antioxidant activity (Hamdi et al. 2018).

\section{Ectopic pregnancy}

If embryo transport in the oviduct does not properly occur (i.e.- if the embryo travels too slowly due to improper regulation of ciliary beating, muscle contractions, or fluid flow), the embryo may implant itself outside of the uterus, known as an ectopic pregnancy. Implantation of embryos in the oviduct (known as a tubal pregnancy) accounts for $90 \%$ of all ectopic pregnancies; the remaining $10 \%$ of ectopic pregnancies occur in the abdominal cavity, interstitial, ovary, and cervix (Panelli et al. 2015). A recent retrospective populationbased longitudinal cohort study showed that women with ectopic first pregnancies had an increased risk of adverse birth outcomes (such as preterm birth, low birth weight and placental abruption) during subsequent intrauterine pregnancies. Furthermore, $10 \%$ of these women had subsequent ectopic pregnancies (Chouinard et al. 2019). Ectopic pregnancy accounts for $5 \%$ of maternal deaths in developed countries and less than $1 \%$ in developing countries (Khan et al. 2006). This is mainly due to ruptures at the site of implantation leading to internal bleeding. Many factors may contribute to increasing the likelihood of ectopic pregnancies, including maldeveloped oviducts (infection-induced or anatomical defect), ARTs procedures (due to increased uterine peristalsis in the cervix-to-fundus direction following embryo transfer), as well as improper regulation of oviductal mechanisms (Shaw et al. 2010, Perkins et al. 2015, Rombauts et al. 2015). Interestingly, tubal pregnancies appear to be restricted to primates and this could be due to anatomical differences at the uterotubal junction, known as the intramural segment in humans. Compared to laboratory and farm animals, there is no clear-cut distinction between the endometrium and endosalpinx in primates, leading to mixing of oviductal and uterine fluids and environments which could result in tubal pregnancies (reviewed by Corpa 2006).

Disruption of estrogen signaling from exposure to endocrine disruptors such as bisphenol A (BPA), used for manufacturing plastics, has been shown to increase the incidence of embryo retention in mouse oviducts (Xiao et al. 2011). Some plastics used for ARTs have been found to contain BPA (Gatimel et al. 2016). Although the levels are low in these products, BPA could negatively impact embryo quality and implantation (Ehrlich et al. 2012).
As discussed previously, oviductal microenvironments play a role in transporting and nurturing developing embryos before implantation through fluid secretions, ciliary beating, and tubal muscle contractions. Ji et al. showed that expression of AQP9 is decreased in oviduct tissues collected from patients who had ectopic pregnancies (Ji et al. 2013). In addition to AQP, the presence of MUC1, a glycoprotein expressed in epithelial cells of the upper reproductive tract, inhibits embryo implantation by acting as an anti-adhesive molecule (Aplin et al. 2001). MUC1 expression on the apical membrane of uterine epithelial cells is lost shortly before embryo attachment (Aplin et al. 2001). Aplin et al. also showed that MUC1 protein was detected on the epithelial surface of ampulla in both humans and monkeys, suggesting that the presence of MUC1 may provide anti-adhesive activity against embryo attachment in the oviduct preventing ectopic pregnancy. Accordingly, ectopic pregnancy is associated with low MUC1 expression (Al-Azemi et al. 2009). These data together demonstrate that secretory cells are necessary for normal embryo transport in the oviduct.

In addition to the secretory cells, ciliated epithelial cells in the oviduct also facilitate proper embryo transport. In rats, levonorgestrel (a synthetic $\mathrm{P}_{4}$ analog used in plan B contraceptive pills) decreases $\mathrm{CBF}$ in the oviduct (Zhao et al. 2015). In humans, increased circulating levels of levonorgestrel have also been associated with ectopic pregnancies (Sheffer-Mimouni et al. 2003, Graner et al. 2019). Recently Li et al. demonstrated that levonorgestrel decreases expression of TRPV4 channels in human fallopian tubal epithelial cell line OE-E6/E7 (Li et al. 2019). Cultured primary ciliated epithelial cells of human oviducts treated with levonorgestrel showed a significant reduction of CBF in a TRPV4-dependent manner (Li et al. 2019). In fact, oviducts from patients with ectopic pregnancies have significantly lower levels of TRPV4 protein expression (Li et al. 2019).

In addition to the effect of high levels of $\mathrm{P}_{4}$, cigarette smoking also increases risk of ectopic pregnancies (1.6-3.5 times higher in smokers vs non-smokers) (Saraiya et al. 1998). Exposure to cigarette smoke significantly decreases CBF of ciliated epithelial cells in hamster oviducts (Knoll et al. 1995). Inhalation of cigarette smoke not only affects ciliary function, but it also slows muscle contractions in hamster oviducts (DiCarlantonio \& Talbot 1999). Together these findings suggest that excess exposure to $\mathrm{P}_{4}$ (or synthetic $\mathrm{P}_{4}$ ) as well as cigarette smoking can cause a disruption in ciliated epithelial and muscle cell functions in the oviduct and could result in ectopic pregnancies.

\section{Conclusion}

Regulation of the mechanical processes in the oviduct including the physiological function of secretory, 
ciliated, and muscle cells is crucial for maintaining proper embryo quality and transport within the oviduct, along with supporting various sperm functions. Alterations in steroid hormone signaling can result in the disruption of normal embryo development and can also lead to ectopic pregnancies or infertility.

\section{Declaration of interest}

The authors declare that there is no conflict of interest that could be perceived as prejudicing the impartiality of this review.

\section{Funding}

This work was supported by grants from the Eunice Kennedy Shriver National Institute of Child Health \& Human Development of the National Institutes of Health (award number R01 HD097087) and the start-up fund from Washington State University, College of Veterinary Medicine to W W and the National Heart, Lung, and Blood Institute (award number R01HL139643) to K-I T.

\section{Author contribution statement}

B E B, G G H, P A, J K R, A M W, and E A H wrote and edited the paper. G G H, A M W and E A H performed histological staining, immunostaining and analyzed data. K-I T provided human oviduct samples, wrote and edited the paper. W W conceived the study, analyzed data, wrote and edited the paper.

\section{Acknowledgements}

The authors thank Lana Lim for an initial contribution of the manuscript and acknowledge the Stony Brook University Medicine (SBUM) BioBank, a Department of Pathology and Cancer Center Core Facility at the Stony Brook University School of Medicine for human oviduct specimens.

\section{References}

Abe H 1996 The mammalian oviductal epithelium: regional variations in cytological and functional aspects of the oviductal secretory cells. Histology and Histopathology 11 743-768.

Adeoya-Osiguwa SA, Markoulaki S, Pocock V, Milligan SR \& Fraser LR 2003 17beta-Estradiol and environmental estrogens significantly affect mammalian sperm function. Human Reproduction 18 100-107. (https:// doi.org/10.1093/humrep/deg037)

Aguilar J \& Reyley M 2005 The uterine tubal fluid: secretion, composition and biological effects. Animal Reproduction 2 91-105.

Akison LK, Boden MJ, Kennaway DJ, Russell DL \& Robker RL 2014 Progesterone receptor-dependent regulation of genes in the oviducts of female mice. Physiological Genomics 46 583-592. (https://doi. org/10.1152/physiolgenomics.00044.2014)

Al-Alem L, Bridges PJ, Su W, Gong MC, Iglarz M \& Ko C 2007 Endothelin-2 induces oviductal contraction via endothelin receptor subtype a in rats. Journal of Endocrinology 193 383-391. (https://doi.org/10.1677/JOE-070089)

Al-Azemi M, Refaat B, Aplin J \& Ledger W 2009 The expression of muc1 in human fallopian tube during the menstrual cycle and in ectopic pregnancy. Human Reproduction 24 2582-2587. (https://doi. org/10.1093/humrep/dep233)
Algarra B, Han L, Soriano-Ubeda C, Aviles M, Coy P, Jovine L \& JimenezMovilla M 2016 The C-terminal region of ovgp1 remodels the zona pellucida and modifies fertility parameters. Scientific Reports 632556. (https://doi.org/10.1038/srep32556)

Algarra B, Maillo V, Aviles M, Gutierrez-Adan A, Rizos D \& JimenezMovilla M 2018 Effects of recombinant OVGP1 protein on in vitro bovine embryo development. Journal of Reproduction and Development 64 433-443. (https://doi.org/10.1262/jrd.2018-058)

Almiñana C, Corbin E, Tsikis G, Alcântara-Neto AS, Labas V, Reynaud K, Galio L, Uzbekov R, Garanina AS, Druart X et al. 2017 Oviduct extracellular vesicles protein content and their role during oviduct-embryo cross-talk. Reproduction 154 153-168. (https://doi.org/10.1530/REP-17-0054)

Alminana C, Tsikis G, Labas V, Uzbekov R, Da Silveira JC, Bauersachs S \& Mermillod P 2018 Deciphering the oviductal extracellular vesicles content across the estrous cycle: implications for the gametes-oviduct interactions and the environment of the potential embryo. BMC Genomics 19 622. (https://doi.org/10.1186/s12864-018-4982-5)

Andrade YN, Fernandes J, Vazquez E, Fernandez-Fernandez JM, Arniges M, Sanchez TM, Villalon M \& Valverde MA 2005 TRPV4 channel is involved in the coupling of fluid viscosity changes to epithelial ciliary activity. Journal of Cell Biology 168 869-874. (https://doi.org/10.1083/ jcb.200409070)

Aplin JD, Meseguer M, Simon C, Ortíz ME, Croxatto H \& Jones CJP 2001 $\mathrm{MUCl}$, glycans and the cell-surface barrier to embryo implantation. Biochemical Society Transactions 29 153-156. (https://doi. org/10.1042/0300-5127:0290153)

Araki Y, Nohara M, Yoshida-Komiya H, Kuramochi T, Ito M, Hoshi H, Shinkai Y \& Sendai Y 2003 Effect of a null mutation of the oviductspecific glycoprotein gene on mouse fertilization. Biochemical Journal 374 551-557. (https://doi.org/10.1042/BJ20030466)

Avilés M, Gutiérrez-Adán A \& Coy P 2010 Oviductal secretions: will they be key factors for the future arts? Molecular Human Reproduction 16 896-906. (https://doi.org/10.1093/molehr/gaq056)

Bauersachs S, Blum H, Mallok S, Wenigerkind H, Rief S, Prelle K \& Wolf E 2003 Regulation of ipsilateral and contralateral bovine oviduct epithelial cell function in the postovulation period: a transcriptomics approach. Biology of Reproduction 68 1170-1177. (https://doi.org/10.1095/ biolreprod.102.010660)

Bishop DW 1956 Active secretion in the rabbit oviduct. American Journal of Physiology 187 347-352. (https://doi.org/10.1152/ ajplegacy.1956.187.2.347)

Bongso A, Soon-Chye N, Sathananthan H, Lian NP, Rauff M \& Ratnam S 1989 Improved quality of human embryos when co-cultured with human ampullary cells. Human Reproduction 4 706-713. (https://doi. org/10.1093/oxfordjournals.humrep.a136971)

Brañes MC, Morales B, Ríos M \& Villalón MJ 2005 Regulation of the immunoexpression of aquaporin 9 by ovarian hormones in the rat oviductal epithelium. American Journal of Physiology: Cell Physiology 288 C1048-C1057. (https://doi.org/10.1152/ajpcell.00420.2003)

Braude P, Bolton V \& Moore S 1988 Human gene expression first occurs between the four- and eight-cell stages of preimplantation development. Nature 332 459-461. (https://doi.org/10.1038/332459a0)

Brenner RM 1969 Renewal of oviduct cilia during the menstrual cycle of the rhesus monkey. Fertility and Sterility 20 599-611. (https://doi. org/10.1016/s0015-0282(16)37086-8)

Buhi WC, Ashworth CJ, Bazer FW \& Alvarez IM 1992 In vitro synthesis of oviductal secretory proteins by estrogen-treated ovariectomized gilts. Journal of Experimental Zoology 262 426-435. (https://doi.org/10.1002/ jez.1402620409)

Bylander A, Nutu M, Wellander R, Goksor M, Billig H \& Larsson DG 2010 Rapid effects of progesterone on ciliary beat frequency in the mouse Fallopian tube. Reproductive Biology and Endocrinology 8 48. (https:// doi.org/10.1186/1477-7827-8-48)

Bylander A, Lind K, Goksor M, Billig H \& Larsson DG 2013 The classical progesterone receptor mediates the rapid reduction of fallopian tube ciliary beat frequency by progesterone. Reproductive Biology and Endocrinology 11 33. (https://doi.org/10.1186/1477-7827-11-33)

Canovas S, Ivanova E, Romar R, Garcia-Martinez S, Soriano-Ubeda C, Garcia-Vazquez FA, Saadeh H, Andrews S, Kelsey G \& Coy P 2017 DNA methylation and gene expression changes derived from assisted reproductive technologies can be decreased by reproductive fluids. eLife 6 e23670. (https://doi.org/10.7554/eLife.23670) 
Castro PT, Aranda OL, Matos APP, Marchiori E, De Araujo LFB, Alves HDL, Machado AS, Lopes RT, Werner H \& Junior EA 2019 The human endosalpinx: anatomical three-dimensional study and reconstruction using confocal microtomography. Polish Journal of Radiology 84 e281e288. (https://doi.org/10.5114/pjr.2019.86824)

Chen S, Einspanier R \& Schoen J 2013 Long-term culture of primary porcine oviduct epithelial cells: validation of a comprehensive in vitro model for reproductive science. Theriogenology 80 862-869. (https:// doi.org/10.1016/j.theriogenology.2013.07.011)

Chouinard M, Mayrand MH, Ayoub A, Healy-Profitos J \& Auger N 2019 Ectopic pregnancy and outcomes of future intrauterine pregnancy. Fertility and Sterility 112 112-119. (https://doi.org/10.1016/j. fertnstert.2019.03.019)

Conneely OM, Mulac-Jericevic B \& Lydon JP 2003 Progesterone-dependent regulation of female reproductive activity by two distinct progesterone receptor isoforms. Steroids 68 771-778. (https://doi.org/10.1016/s0039$128 x(03) 00126-0)$

Corpa JM 2006 Ectopic pregnancy in animals and humans. Reproduction 131 631-640. (https://doi.org/10.1530/rep.1.00606)

Coy P \& Yanagimachi R 2015 The common and species-specific roles of oviductal proteins in mammalian fertilization and embryo development. BioScience 65 973-984. (https://doi.org/10.1093/biosci/biv119)

Coy P, Cánovas S, Mondéjar I, Saavedra MD, Romar R, Grullón L, Matás C \& Avilés M 2008 Oviduct-specific glycoprotein and heparin modulate sperm-zona pellucida interaction during fertilization and contribute to the control of polyspermy. PNAS 105 15809-15814. (https://doi. org/10.1073/pnas.0804422105)

Croxatto HB 2002 Physiology of gamete and embryo transport through the Fallopian tube. Reproductive Biomedicine Online 4 160-169. (https:// doi.org/10.1016/s1472-6483(10)61935-9)

De Geyter C, Calhaz-Jorge C, Kupka MS, Wyns C, Mocanu E, Motrenko T, Scaravelli G, Smeenk J, Vidakovic S, Goossens V et al. 2018 ART in Europe, 2014: results generated from European registries by eshre: the European IVF-monitoring consortium (EIM) for the European Society of Human Reproduction and Embryology (ESHRE). Human Reproduction 33 1586-1601. (https://doi.org/10.1093/humrep/dey242)

Dicarlantonio G \& Talbot P 1999 Inhalation of mainstream and sidestream cigarette smoke retards embryo transport and slows muscle contraction in oviducts of hamsters (Mesocricetus auratus). Biology of Reproduction 61 651-656. (https://doi.org/10.1095/biolreprod61.3.651)

Dietzel E, Wessling J, Floehr J, Schäfer C, Ensslen S, Denecke B, Rösing B, Neulen J, Veitinger T, Spehr M et al. 2013 Fetuin-b, a liver-derived plasma protein is essential for fertilization. Developmental Cell $\mathbf{2 5}$ 106-112. (https://doi.org/10.1016/j.devcel.2013.03.001)

Dirksen ER \& Satir P 1972 Ciliary activity in the mouse oviduct as studied by transmission and scanning electron microscopy. Tissue and Cell $\mathbf{4}$ 389-403. (https://doi.org/10.1016/s0040-8166(72)80017-x)

Dixon RE, Ramsey KH, Schripsema JH, Sanders KM \& Ward SM 2010 Time-dependent disruption of oviduct pacemaker cells by chlamydia infection in mice. Biology of Reproduction 83 244-253. (https://doi. org/10.1095/biolreprod.110.083808)

Dixon RE, Hennig GW, Baker SA, Britton FC, Harfe BD, Rock JR, Sanders KM \& Ward SM 2012 Electrical slow waves in the mouse oviduct are dependent upon a calcium activated chloride conductance encoded by Tmem16a. Biology of Reproduction 86 1-7. (https://doi. org/10.1095/biolreprod.111.095554)

Eddy EM, Washburn TF, Bunch DO, Goulding EH, Gladen BC, Lubahn DB \& Korach KS 1996 Targeted disruption of the estrogen receptor gene in male mice causes alteration of spermatogenesis and infertility. Endocrinology 137 4796-4805. (https://doi.org/10.1210/endo.137.11.8895349)

Ehrlich S, Williams PL, Missmer SA, Flaws JA, Berry KF, Calafat AM, Ye X, Petrozza JC, Wright D \& Hauser R 2012 Urinary bisphenol A concentrations and implantation failure among women undergoing in vitro fertilization. Environmental Health Perspectives 120 978-983. (https://doi.org/10.1289/ehp.1104307)

Ferraz MAMM, Henning HHW, Stout TAE, Vos PLAM \& Gadella BM 2017 Designing 3-dimensional in vitro oviduct culture systems to study mammalian fertilization and embryo production. Annals of Biomedical Engineering 45 1731-1744. (https://doi.org/10.1007/s10439-016-1760-x)

Fujihara Y, Miyata H \& Ikawa M 2018 Factors controlling sperm migration through the oviduct revealed by gene-modified mouse models. Experimental Animals 67 91-104. (https://doi.org/10.1538/ expanim.17-0153)
Gatimel N, Lacroix MZ, Chanthavisouk S, Picard-Hagen N, Gayrard V, Parinaud J \& Léandri RD 2016 Bisphenol A in culture media and plastic consumables used for art. Human Reproduction 31 1436-1444. (https:// doi.org/10.1093/humrep/dew116)

Ghosh A, Syed SM \& Tanwar PS 2017 In vivo genetic cell lineage tracing reveals that oviductal secretory cells self-renew and give rise to ciliated cells. Development 144 3031-3041. (https://doi.org/10.1242/ dev.149989)

Gott AL, Gray SM, James AF \& Leese HJ 1988 The mechanism and control of rabbit oviduct fluid formation. Biology of Reproduction 39 758-763. (https://doi.org/10.1095/biolreprod39.4.758)

Graner S, Mc Taggart J, Nordström F, Melander E, Widenberg J \& Kopp Kallner H 2019 Levonorgestrel intrauterine contraceptive systems (13.5 mg and $52 \mathrm{mg}$ ) and risk of ectopic pregnancy. Acta Obstetricia et Gynecologica Scandinavica 98 937-943. (https://doi.org/10.1111/ aogs.13564)

Halbert SA, Tam PY \& Blandau RJ 1976 Egg transport in the rabbit oviduct: the roles of cilia and muscle. Science 191 1052-1053. (https://doi. org/10.1126/science.1251215)

Halbert SA, Becker DR \& Szal SE 1989 Ovum transport in the rat oviductal ampulla in the absence of muscle contractility. Biology of Reproduction 40 1131-1136. (https://doi.org/10.1095/biolreprod40.6.1131)

Hamdi M, Lopera-Vasquez R, Maillo V, Sanchez-Calabuig MJ, Nunez C, Gutierrez-Adan A \& Rizos D 2018 Bovine oviductal and uterine fluid support in vitro embryo development. Reproduction Fertility and Development 30 935-945. (https://doi.org/10.1071/RD17286)

Hamner CE \& Fox SB 1968 Effect of oestrogen and progesterone on physical properties of rabbit oviduct fluid. Journal of Reproduction and Fertility 16 121-122. (https://doi.org/10.1530/jrf.0.0160121)

Hewitt SC, Winuthayanon W \& Korach KS 2016 What's new in estrogen receptor action in the female reproductive tract. Journal of Molecular Endocrinology 56 R55-R71. (https://doi.org/10.1530/JME-15-0254)

Hino T \& Yanagimachi R 2019 Active peristaltic movements and fluid production of the mouse oviduct: their roles in fluid and sperm transport and fertilization. Biology of Reproduction 101 40-49. (https://doi. org/10.1093/biolre/ioz061)

Holt WV \& Fazeli A 2010 The oviduct as a complex mediator of mammalian sperm function and selection. Molecular Reproduction and Development 77 934-943. (https://doi.org/10.1002/mrd.21234)

Huang N, Liu B, Dong Z, Mao W, Zhang N, Li C \& Cao J 2015 Prostanoid receptors $\mathrm{EP} 2, \mathrm{EP} 4$, and $\mathrm{FP}$ are regulated by estradiol in bovine oviductal smooth muscle. Prostaglandins and Other Lipid Mediators 121 170-175. (https://doi.org/10.1016/j.prostaglandins.2015.08.002)

Huang N, Wang C, Zhang N, Mao W, Liu B, Shen Y, Gao Y, Zhao Y \& Cao J 2018 Effect of estrogen on prostaglandin synthetase in bovine oviduct smooth muscle. European Journal of Pharmacology 818 287-293. (https://doi.org/10.1016/j.ejphar.2017.10.058)

Hunter RHF 1988 Development of the fallopian tubes and their functional anatony. In The Fallopian Tubes: Their Role in Fertility and Infertility, pp 12-29. Ed RHF Hunter. Berlin, Germany: Springer-Verlag.

Ji YF, Chen LY, Xu KH, Yao JF, Shi YF \& Shanguan XJ 2013 Reduced expression of aquaporin 9 in tubal ectopic pregnancy. Journal of Molecular Histology 44 167-173. (https://doi.org/10.1007/s10735-0129471-6)

Jung C, Fandos C, Lorenzo IM, Plata C, Fernandes J, Gene GG, Vazquez E \& Valverde MA 2009 The progesterone receptor regulates the expression of TRPV4 channel. Pflugers Archiv 459 105-113. (https://doi.org/10.1007/ s00424-009-0706-7)

Kapur RP \& Johnson LV 1986 Selective sequestration of an oviductal fluid glycoprotein in the perivitelline space of mouse oocytes and embryos. Journal of Experimental Zoology 238 249-260. (https://doi.org/10.1002/ jez.1402380215)

Khan KS, Wojdyla D, Say L, Gülmezoglu AM \& Van Look PF 2006 Who analysis of causes of maternal death: a systematic review. Lancet $\mathbf{3 6 7}$ 1066-1074. (https://doi.org/10.1016/S0140-6736(06)68397-9)

Knoll M, Shaoulian R, Magers T \& Talbot P 1995 Ciliary beat frequency of hamster oviducts is decreased in vitro by exposure to solutions of mainstream and sidestream cigarette smoke. Biology of Reproduction $\mathbf{5 3}$ 29-37. (https://doi.org/10.1095/biolreprod53.1.29)

Kowalik MK, Slonina D, Rekawiecki R \& Kotwica J 2013 Expression of progesterone receptor membrane component (PGRMC) 1 and 2, serpine mRNA binding protein 1 (SERBP1) and nuclear progesterone receptor (pgr) in the bovine endometrium during the estrous cycle and the first 
trimester of pregnancy. Reproductive Biology 13 15-23. (https://doi. org/10.1016/j.repbio.2013.01.170)

Lai YM, Wang HS, Lee CL, Lee JD, Huang HY, Chang FH, Lee JF \& Soong YK 1996 Insulin-like growth factor-binding proteins produced by vero cells, human oviductal cells and human endometrial cells, and the role of insulin-like growth factor-binding protein-3 in mouse embryo co-culture systems. Human Reproduction 11 1281-1286. (https://doi.org/10.1093/ oxfordjournals.humrep.a019372)

Lee KF, Xu JS, Lee YL \& Yeung WS 2006 Demilune cell and parotid protein from murine oviductal epithelium stimulates preimplantation embryo development. Endocrinology 147 79-87. (https://doi.org/10.1210/ en.2005-0596)

Li S, O'Neill SRS, Zhang Y, Holtzman MJ, Takemaru KI, Korach KS \& Winuthayanon W 2017 Estrogen receptor $\alpha$ is required for oviductal transport of embryos. FASEB Journal 31 1595-1607. (https://doi. org/10.1096/fj.201601128R)

Li C, Wu YT, Zhu Q, Zhang HY, Huang Z, Zhang D, Qi H, Liang GL, He XQ, Wang XF et al. 2019 TRPV4 is involved in levonorgestrelinduced reduction in oviduct ciliary beating. Journal of Pathology $\mathbf{2 4 8}$ 77-87. (https://doi.org/10.1002/path.5233)

Lishko PV, Botchkina IL \& Kirichok Y 2011 Progesterone activates the principal Ca2+ channel of human sperm. Nature 471 387-391. (https:// doi.org/10.1038/nature09767)

Lopera-Vasquez R, Hamdi M, Maillo V, Gutierrez-Adan A, BermejoAlvarez P, Ramirez MÁ, Yanez-Mo M \& Rizos D 2017 Effect of bovine oviductal extracellular vesicles on embryo development and quality in vitro. Reproduction 153 461-470. (https://doi.org/10.1530/REP-16-0384)

Lorenzo IM, Liedtke W, Sanderson MJ \& Valverde MA 2008 TRPV4 channel participates in receptor-operated calcium entry and ciliary beat frequency regulation in mouse airway epithelial cells. PNAS $\mathbf{1 0 5}$ 12611-12616. (https://doi.org/10.1073/pnas.0803970105)

Lydon JP, Demayo FJ, Funk CR, Mani SK, Hughes AR, Montgomery Jr CA, Shyamala G, Conneely OM \& O'Malley BW 1995 Mice lacking progesterone receptor exhibit pleiotropic reproductive abnormalities. Genes and Development 9 2266-2278. (https://doi.org/10.1101/ gad.9.18.2266)

Lyng R \& Shur BD 2009 Mouse oviduct-specific glycoprotein is an eggassociated ZP3-independent sperm-adhesion ligand. Journal of Cell Science 122 3894-3906. (https://doi.org/10.1242/jcs.058776)

Mahmood T, Saridogan E, Smutna S, Habib AM \& Djahanbakhch O 1998 The effect of ovarian steroids on epithelial ciliary beat frequency in the human fallopian tube. Human Reproduction 13 2991-2994. (https://doi. org/10.1093/humrep/13.11.2991)

McDonald MF \& Bellve AR 1969 Influence of oestrogen and progesterone on flow of fluid from the fallopian tube in the ovariectomized ewe. Journal of Reproduction and Fertility 20 51-61. (https://doi.org/10.1530/ jif.0.0200051)

Miki K \& Clapham DE 2013 Rheotaxis guides mammalian sperm. Current Biology 23 443-452. (https://doi.org/10.1016/j.cub.2013.02.007)

Moore EL, Wang S \& Larina IV 2018 Staging mouse preimplantation development in vivo using optical coherence microscopy. Journal of Biophotonics 12 e201800364.

Muglia U \& Motta PM 2001 A new morpho-functional classification of the fallopian tube based on its three-dimensional myoarchitecture. Histology and Histopathology 16 227-237.

Mulac-Jericevic B, Lydon JP, Demayo FJ \& Conneely OM 2003 Defective mammary gland morphogenesis in mice lacking the progesterone receptor b isoform. PNAS 100 9744-9749. (https://doi.org/10.1073/ pnas.1732707100)

Muro $Y$, Hasuwa $H$, Isotani A, Miyata $H$, Yamagata $K$, Ikawa $M$, Yanagimachi R \& Okabe M 2016 Behavior of mouse spermatozoa in the female reproductive tract from soon after mating to the beginning of fertilization. Biology of Reproduction 94 80. (https://doi.org/10.1095/ biolreprod.115.135368)

Nah WH, Oh YS, Hwang JH \& Gye MC 2017 Changes in aquaporin 5 in the non-ciliated cells of mouse oviduct according to sexual maturation and oestrous cycle. Reproduction Fertility and Development 29 336-344. (https://doi.org/10.1071/RD15186)

Niwa S, Nakajima K, Miki H, Minato Y, Wang D \& Hirokawa N 2012 KIF19A is a microtubule-depolymerizing kinesin for ciliary length control. Developmental Cell 23 1167-1175. (https://doi.org/10.1016/j. devcel.2012.10.016)
Nutu M, Weijdegard B, Thomas P, Thurin-Kjellberg A, Billig H \& Larsson DG 2009 Distribution and hormonal regulation of membrane progesterone receptors beta and gamma in ciliated epithelial cells of mouse and human fallopian tubes. Reproductive Biology and Endocrinology 789. (https://doi.org/10.1186/1477-7827-7-89)

Okabe M 2015 Mechanisms of fertilization elucidated by genemanipulated animals. Asian Journal of Andrology 17 646-652. (https:// doi.org/10.4103/1008-682X.153299)

Okada A, Ohta Y, Inoue S, Hiroi H, Muramatsu M \& Iguchi T 2003 Expression of estrogen, progesterone and androgen receptors in the oviduct of developing, cycling and pre-implantation rats. Journal of Molecular Endocrinology 30 301-315. (https://doi.org/10.1677/ jme.0.0300301)

Okada A, Ohta Y, Brody SL, Watanabe H, Krust A, Chambon P \& Iguchi T 2004 Role of FOXJ1 and estrogen receptor alpha in ciliated epithelial cell differentiation of the neonatal oviduct. Journal of Molecular Endocrinology 32 615-625. (https://doi.org/10.1677/jme.0.0320615)

Oren-Benaroya R, Orvieto R, Gakamsky A, Pinchasov M \& Eisenbach M 2008 The sperm chemoattractant secreted from human cumulus cells is progesterone. Human Reproduction 23 2339-2345. (https://doi. org/10.1093/humrep/den265)

Panelli DM, Phillips CH \& Brady PC 2015 Incidence, diagnosis and management of tubal and nontubal ectopic pregnancies: a review. Fertility Research and Practice 1 15. (https://doi.org/10.1186/s40738015-0008-z)

Parada-Bustamante A, Croxatto HB, Cárdenas H \& Orihuela PA 2012 Differential participation of endothelin receptors in estradiol-induced oviductal egg transport acceleration in unmated and mated rats. Asian Pacific Journal of Reproduction 1 22-26. (https://doi.org/10.1016/ S2305-0500(13)60042-1)

Pauerstein CJ \& Eddy CA 1979 Morphology of the Fallopian tube. In The Biology of the Fluids of the Female Reproductive Tract, pp 299-317. Eds FK Beller \& GFB Schumacher. Amsterdam: Elsevier.

Pérez Martínez S, Hermoso $M$, Farina $M$, Ribeiro ML, Rapanelli $M$, Espinosa M, Villalón M \& Franchi A 2006 17- $\beta$-Estradiol upregulates COX-2 in the rat oviduct. Prostaglandins and Other Lipid Mediators 80 155-164. (https://doi.org/10.1016/j.prostaglandins.2006.06.002)

Perkins KM, Boulet SL, Kissin DM, Jamieson DJ \& National ART Surveillance (NASS) Group 2015 Risk of ectopic pregnancy associated with assisted reproductive technology in the United States, 2001-2011. Obstetrics and Gynecology 125 70-78. (https://doi.org/10.1097/ AOG.0000000000000584)

Popescu LM, Ciontea SM, Cretoiu D, Hinescu ME, Radu E, lonescu N, Ceausu M, Gherghiceanu M, Braga RI, Vasilescu F et al. 2005 Novel type of interstitial cell (Cajal-like) in human Fallopian tube. Journal of Cellular and Molecular Medicine 9 479-523. (https://doi. org/10.1111/j.1582-4934.2005.tb00376.x)

Priyadarsana M, Wijayagunawardane B \& Miyamoto A 2004 Endothelin-1 system in the bovine oviduct: a regulator of local contraction and gamete transport. Journal of Cardiovascular Pharmacology $\mathbf{4 4}$ (Supplement 1) S248-S251. (https://doi. org/10.1097/01.fjc.0000166253.66486.4f)

Qu P, Zhao Y, Wang R, Zhang Y, Li L, Fan J \& Liu E 2019 Extracellular vesicles derived from donor oviduct fluid improved birth rates after embryo transfer in mice. Reproduction Fertility and Development 31 324-332. (https://doi.org/10.1071/RD18203)

Reuquén P, Oróstica ML, Rojas I, Diaz P, Parada Bustamante A \& Orihuela PA 2015 Estradiol increases IP3 by a nongenomic mechanism in the smooth muscle cells from the rat oviduct. Reproduction $\mathbf{1 5 0}$ 331-341. (https://doi.org/10.1530/REP-15-0137)

Roberts GP, Parker JM \& Symonds HW 1975 Proteins in the luminal fluid from the bovine oviduct. Journal of Reproduction and Fertility $\mathbf{4 5}$ 301-313. (https://doi.org/10.1530/jrf.0.0450301)

Rombauts L, Mcmaster R, Motteram C \& Fernando S 2015 Risk of ectopic pregnancy is linked to endometrial thickness in a retrospective cohort study of 8120 assisted reproduction technology cycles. Human Reproduction 30 2846-2852. (https://doi.org/10.1093/humrep/dev249)

Rosselli M, Imthurn B, Macas E \& Keller PJ 1994a Endothelin production by bovine oviduct epithelial cells. Journal of Reproduction and Fertility 101 27-30. (https://doi.org/10.1530/jrf.0.1010027)

Rosselli M, Imthurn B, Macas E, Keller PJ \& Dubey RK $1994 b$ Endogenous nitric oxide modulates endothelin-1 induced contraction of bovine 
oviduct. Biochemical and Biophysical Research Communications 201 143-148. (https://doi.org/10.1006/bbrc.1994.1680)

Sabeur K, Edwards DP \& Meizel S 1996 Human sperm plasma membrane progesterone receptor(s) and the acrosome reaction. Biology of Reproduction 54 993-1001. (https://doi.org/10.1095/ biolreprod54.5.993)

Saraiya M, Berg CJ, Kendrick JS, Strauss LT, Atrash HK \& Ahn YW 1998 Cigarette smoking as a risk factor for ectopic pregnancy. American Journal of Obstetrics and Gynecology 178 493-498. (https://doi. org/10.1016/s0002-9378(98)70427-2)

Seki K, Rawson J, Eddy CA, Smith NK \& Pauerstein CJ 1978 Deciliation in the puerperal Fallopian tube. Fertility and Sterility 29 75-83. (https://doi. org/10.1016/S0015-0282(16)43042-6)

Sfontouris IA, Martins WP, Nastri CO, Viana IGR, Navarro PA, RaineFenning N, Van Der Poel S, Rienzi L \& Racowsky C 2016 Blastocyst culture using single versus sequential media in clinical IVF: a systematic review and meta-analysis of randomized controlled trials. Journal of Assisted Reproduction and Genetics 33 1261-1272. (https://doi. org/10.1007/s10815-016-0774-5)

Shaw JL, Dey SK, Critchley HO \& Horne AW 2010 Current knowledge of the aetiology of human tubal ectopic pregnancy. Human Reproduction Update 16 432-444. (https://doi.org/10.1093/humupd/dmp057)

Sheffer-Mimouni G, Pauzner D, Maslovitch S, Lessing JB \& Gamzu R 2003 Ectopic pregnancies following emergency levonorgestrel contraception. Contraception 67 267-269. (https://doi.org/10.1016/ s0010-7824(02)00539-5)

Siller SS, Sharma H, Li S, Yang J, Zhang Y, Holtzman MJ, Winuthayanon W, Colognato H, Holdener BC, Li FQ et al. 2017 Conditional knockout mice for the distal appendage protein CEP164 reveal its essential roles in airway multiciliated cell differentiation. PLoS Genetics 13 e1007128. (https://doi.org/10.1371/journal.pgen.1007128)

Skowronski MT, Skowronska A \& Nielsen S 2011 Fluctuation of aquaporin 1,5 , and 9 expression in the pig oviduct during the estrous cycle and early pregnancy. Journal of Histochemistry and Cytochemistry $\mathbf{5 9}$ 419-427. (https://doi.org/10.1369/0022155411400874)

Solakidi S, Psarra AM, Nikolaropoulos S \& Sekeris CE 2005 Estrogen receptors alpha and beta (ER $\alpha$ and $E R \beta)$ and androgen receptor $(A R)$ in human sperm: localization of $E R \beta$ and $A R$ in mitochondria of the midpiece. Human Reproduction 20 3481-3487. (https://doi org/10.1093/humrep/dei267)

Spilman CH 1974 Oviduct response to prostaglandins: influence of estradiol and progesterone. Prostaglandins 7 465-472. (https://doi. org/10.1016/0090-6980(74)90091-4)

Steffl M, Schweiger M, Sugiyama T \& Amselgruber WM 2008 Review of apoptotic and non-apoptotic events in non-ciliated cells of the mammalian oviduct. Annals of Anatomy 190 46-52. (https://doi. org/10.1016/j.aanat.2007.04.003)

Suarez SS 2002 Formation of a reservoir of sperm in the oviduct. Reproduction in Domestic Animals 37 140-143. (https://doi. org/10.1046/j.1439-0531.2002.00346.x)

Sunderam S, Kissin DM, Crawford SB, Folger SG, Jamieson DJ, Warner L \& Barfield WD 2017 Assisted reproductive technology surveillance United States, 2014. MMWR: Surveillance Summaries 66 1-24. (https:// doi.org/10.15585/mmwr.ss6606a1)

Tan W, Pang Y, Tubbs C \& Thomas P 2019 Induction of sperm hypermotility through membrane progestin receptor alpha $(\mathrm{mPR} \alpha)$ : a teleost model of rapid, multifaceted, nongenomic progestin signaling. General and
Comparative Endocrinology 279 60-66. (https://doi.org/10.1016/j. ygcen.2018.12.002)

Uyar A \& Seli E 2014 The impact of assisted reproductive technologies on genomic imprinting and imprinting disorders. Current Opinion in Obstetrics and Gynecology 26 210-221. (https://doi.org/10.1097/ GCO.0000000000000071)

Wadhwa PD, Buss C, Entringer S \& Swanson JM 2009 Developmental origins of health and disease: brief history of the approach and current focus on epigenetic mechanisms. Seminars in Reproductive Medicine $\mathbf{2 7}$ 358-368. (https://doi.org/10.1055/s-0029-1237424)

Wang H, Guo Y, Wang D, Kingsley PJ, Marnett LJ, Das SK, Dubois RN \& Dey SK 2004 Aberrant cannabinoid signaling impairs oviductal transport of embryos. Nature Medicine 10 1074-1080. (https://doi.org/10.1038/ nm1104)

Wang S, Burton JC, Behringer RR \& Larina IV 2015 In vivo micro-scale tomography of ciliary behavior in the mammalian oviduct. Scientific Reports 5 13216. (https://doi.org/10.1038/srep13216)

Wessel T, Schuchter U \& Walt H 2004 Ciliary motility in bovine oviducts for sensing rapid non-genomic reactions upon exposure to progesterone. Hormone and Metabolic Research 36 136-141. (https:// doi.org/10.1055/s-2004-814336)

White KL, Hehnke K, Rickords LF, Southern LL, Thompson Jr DL \& Wood TC 1989 Early embryonic development in vitro by coculture with oviductal epithelial cells in pigs. Biology of Reproduction 41 425-430. (https://doi.org/10.1095/biolreprod41.3.425)

Wijayagunawardane MP, Choi YH, Miyamoto A, Kamishita H, Fujimoto S, Takagi M \& Sato K 1999 Effect of ovarian steroids and oxytocin on the production of prostaglandin E2, prostaglandin $\mathrm{F}_{2 \alpha}$ and endothelin-1 from cow oviductal epithelial cell monolayers in vitro. Animal Reproduction Science 56 11-17. (https://doi.org/10.1016/S0378-4320(99)00021-4)

Wijayagunawardane MP, Miyamoto A, Taquahashi Y, Gabler C, Acosta TJ, Nishimura M, Killian G \& Sato K 2001 In vitro regulation of local secretion and contraction of the bovine oviduct: stimulation by luteinizing hormone, endothelin-1 and prostaglandins, and inhibition by oxytocin. Journal of Endocrinology 168 117-130. (https://doi. org/10.1677/joe.0.1680117)

Winuthayanon W, Bernhardt ML, Padilla-Banks E, Myers PH, Edin ML, Lih FB, Hewitt SC, Korach KS \& Williams CJ 2015 Oviductal estrogen receptor alpha signaling prevents protease-mediated embryo death. eLife 4 e10453. (https://doi.org/10.7554/eLife.10453)

Xiao S, Diao H, Smith MA, Song X \& Ye X 2011 Preimplantation exposure to bisphenol A (BPA) affects embryo transport, preimplantation embryo development, and uterine receptivity in mice. Reproductive Toxicology 32 434-441. (https://doi.org/10.1016/j.reprotox.2011.08.010)

Zhao W, Zhu Q, Yan M, Li C, Yuan J, Qin G \& Zhang J 2015 Levonorgestrel decreases cilia beat frequency of human fallopian tubes and rat oviducts without changing morphological structure. Clinical and Experimental Pharmacology and Physiology 42 171-178. (https://doi. org/10.1111/1440-1681.12337)

Received 24 April 2019

First decision 28 May 2019

Revised manuscript received 10 October 2019

Accepted 18 October 2019 